\title{
The 100 Most Cited Publications in Aging Research: A Bibliometric Analysis
}

\author{
Haroon ${ }^{1 \star}$, Yu-Xin Li ${ }^{1}$, Chen-Xu Ye ${ }^{1}$, Tauseef Ahmad ${ }^{2}$, Muhammad Khan ${ }^{3}$, Imranullah Shah ${ }^{4}$, Xiao-Hong Su ${ }^{1}$, \\ Lian-Xi Xing ${ }^{1^{\star \star}}$
}

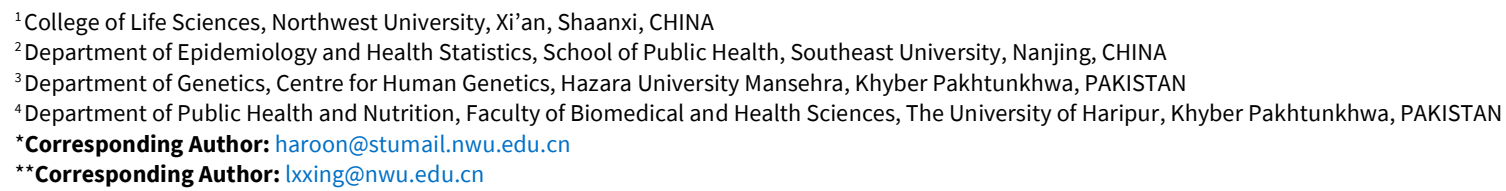

Citation: Haroon, Li Y-X, Ye C-X, Ahmad T, Khan M, Shah I, Su X-H, Xing L-X. The 100 Most Cited Publications in Aging Research: A Bibliometric Analysis. Electron J Gen Med. 2022;19(1):em342. https://doi.org/10.29333/ejgm/11413

\section{ARTICLE INFO}

Received: 7 Oct. 2021

Accepted: 15 Nov. 2021

\begin{abstract}
Aim: The basic aim of this analysis was to evaluate the 100 most cited publications in aging research.

Methods: On January 17, 2021 Web of Science Core Collection database was searched for aging research publications. The studied parameter includes; publication year, authorship, publication type, keywords, journal name, institution, country, and visualization mapping. HistCite ${ }^{\mathrm{TM}}$ application for citation analysis and VOSviewer software was used for visualization mapping.

Results: The top 100 most cited papers were published in 52 journals, authored by 537 authors. The most cited paper was "The diagnosis of dementia due to Alzheimer's disease: Recommendations from the National Institute on Aging-Alzheimer's Association workgroups on diagnostic guidelines for Alzheimer's disease," which received 6039 citations (2013 average citations per year). Nature was the most attractive journal ( $n=13)$. Aging was the most dominant used keyword. The maximum number of papers were published in $2005(n=8)$. Harvard University was the leading institute ( $n=13)$, while the United States of America (USA) was the most productive country ( $n=76)$.

Conclusion: The highly cited papers were published in developed countries, and no study was published in lowincome countries.
\end{abstract}

Keywords: aging or ageing, bibliometric analysis, VOSviewer

\section{INTRODUCTION}

Biological aging (evry living organism) involves a broad range of life changes that negatively impact all fundamental biological processes and ultimately lead to loss of organismal homeostasis and eventually death [1,2]. Human aging (related to human lives) annexes the macroscopic changes, including grinding of the skin, wrinkling, loss of muscle, and physical weakness. They are more vulnerable to a wide range of diseases when individuals get older. In particular, cardiac diseases, cancer, and stroke are the most common age-related disorders, including chronic lower respiratory disorders, type 2 diabetes, and neurodegeneration, representing the leading cause of death among the aged [1,3]. The burden of human aging in all nations worldwide is enormous social, medical, and economical. It is crucial and urgent to develop effective interventions to ensure healthy aging [4]. Age-dependent molecular damage accumulates lower DNA or protein stability, energy production, utilization failure, and homeostasis disruption leading to structural and functional decline. Mutations that offer an overall health benefit over a lifetime of the organism are also expected to increase the population frequency, although their phenotypic action in older ages is detrimental $[1,2]$. The evolutionary aging theory predicts that the average life span is higher in organisms where fertility increases with age, and the intrinsic rate of aging develops in response to extrinsic hazards [5].

Model organisms were used extensively to discover the retained aging pathways and assess interventions that improve longevity and aging. Laboratory mice, insects, and rats are commonly used in aging research in laboratory mice with strong genetic backgrounds, short life, ease of feeding, defined genetic manipulation, and environmental risks [4]. All living things age somehow, and it has proven surprisingly difficult to explain why despite years of research $[6,7]$. Why, for example, do our repair mechanisms appear to degrade with age, resulting in the loss of youth natural resilience to minor physical injury and physical stress [8]? The enzyme telomerase is a hot topic in ageing research at the moment, as it is responsible for maintaining the protective "seal" at the end of each chromosome [9]. Telomeres are the names given to these ends [10], and they prevent chromosomes from fusing and causing abnormalities and protecting the chromosome ends from being nibbled away by cell enzymes [7,10,11]. Chromosomes are extremely valuable and must last a lifetime 


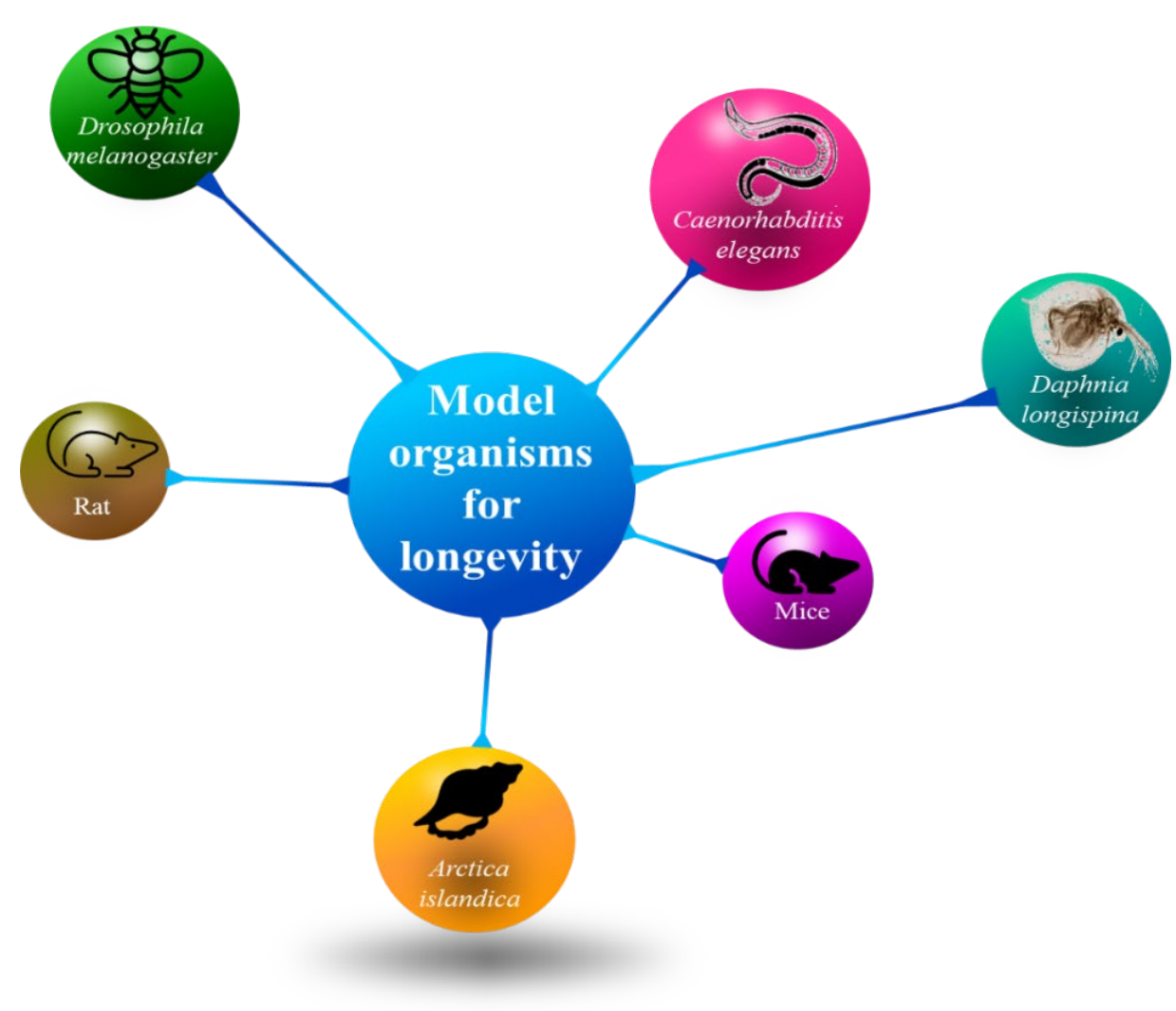

Figure 1. Model organisms for longevity research

[12]. They replicate themselves with each cell division, but this also means that any damage sustained during the division process is passed on to the new cells [13]. The lives of animals are limited from a few weeks (Drosophila melanogaster, Caenorhabditis elegans, and Daphnia longispina) to centuries (Arctica islandica) (Figure 1). Lifespan extension has been of interest for a long time, but longevity mechanisms remain mostly unknown. Invertebrates such as fruit flies or nematodes (fish and mice) with relatively short lifespans are excellent models to study longevity mechanisms. Interestingly, new animal models have been applied for longevity studies under technological developments such as Next-Generation sequencing (NGS) [14].

Bibliometrics analyses; a series of written publications, including journals, books, and scientific publications, using statistical and mathematical tools [15]. It evaluates quantitative research academic output and provides evidence of financing [16]. Bibliometric analysis provides insight into a subject, field, or discipline. It assesses authors, institutions, and countries performance by mapping the structure and dynamics of disciplines utilizing databases [17]. A map understands the information produced in a given field and helps develop public health policies by monitoring its development [15]. Social network analysis for scientific collaboration and co-citation relations is used in bibliometric studies [18]. The international citation indexes, Science Citation Index Expanded (SCI-E), Social Sciences Citation Index $(\mathrm{SSCl})$, and Arts and science quote index are the most critical data sources (A \& $\mathrm{HCl}$ ). The Web of Science Core Collection (WoSCC) database provides access to these indexes [15,19-20]. Thus, the current study was conducted to identify and characterize the 100 most cited publications in aging research.

\section{METHODS}

On January 17, 2021 the WoSCC database was searched using the search keywords ("Aging" OR "Ageing") in title field without restrictions. The 100 most cited papers were included based on the number of citations (Figure 2). The following data were extracted; year of publications, authors, type of publications, journals name, frequently used keywords, institutions, and countries. The data were exported in to HistCite ${ }^{\mathrm{TM}}$ and VOSviewer software for windows for citations count and network visualization mapping respectively. The retrieved data were plotted for co-authorship countries and, co-occurrence author keywords. In this study, no human or animal subjects were involved directly, therefore no ethical consideration was needed.

\section{RESULTS}

The top 100 most cited papers were published in 52 journals with 6716 cited references, 407 keywords, and 537 authors. Among them, 63 were research articles (15996 global citations), and 29 were reviews articles (53923 global citations) (Table 1). The most cited paper was "The diagnosis of dementia due to Alzheimer's disease: Recommendations from the National Institute on Aging-Alzheimer's Association workgroups on diagnostic guidelines for Alzheimer's disease" published by McKhann et al. (2011) received 6039 citations (2013 average citations per year) [21] (Table 2). The most productive year was $2005(n=8)$, while the most cited year was 2011 ( $n=20041$ global citations), as shown in Figure 3A and 3B, respectively. The leading country in aging research was the 


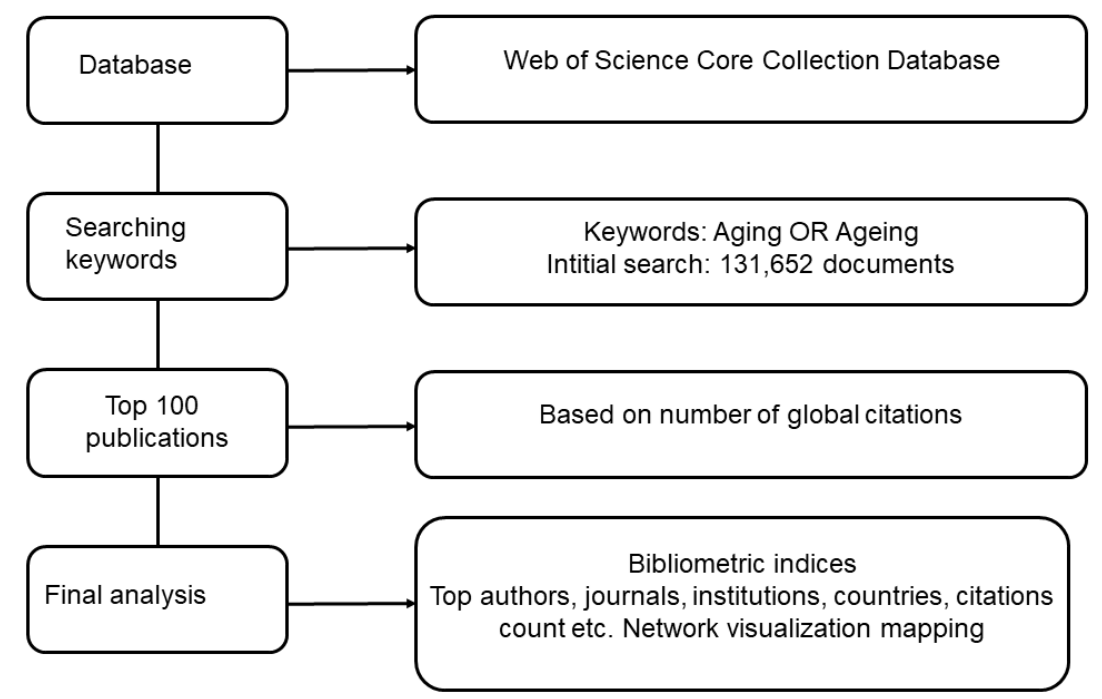

Figure 2. Flow chart of the included publications in final analysis

Table 1. Type of documents

\begin{tabular}{|c|c|c|c|c|}
\hline Document Types & Number & Percent & LCS & GCS \\
\hline Articles & 63 & 63 & 96 & 115996 \\
\hline Reviews & 29 & 29 & 29 & 53923 \\
\hline Proceedings Papers & 4 & 4 & 1 & 5380 \\
\hline Book Chapters & 3 & 3 & 2 & 4453 \\
\hline Notes & 1 & 1 & 3 & 979 \\
\hline
\end{tabular}

LCS: Total local citation score, GCS: Total global citation score

Table 2. Top 100 most cited studies in aging research

\begin{tabular}{|c|c|c|c|c|c|}
\hline Rank & Study reference & $\begin{array}{c}\text { Local } \\
\text { citations }\end{array}$ & $\begin{array}{c}\text { Per } \\
\text { year }\end{array}$ & $\begin{array}{c}\text { Global } \\
\text { citations }\end{array}$ & $\begin{array}{c}\text { Per } \\
\text { year }\end{array}$ \\
\hline 1 & $\begin{array}{l}\text { McKhann GM, et al. The diagnosis of dementia due to Alzheimer's disease: Recommendations from the National Institute on } \\
\text { Aging-Alzheimer's Association workgroups on diagnostic guidelines for Alzheimer's disease. Alzheimers \& Dementia. } 2011 \\
\text { May; 7(3): 263-269. }\end{array}$ & 4 & 1.33 & 6039 & 2013.00 \\
\hline 2 & Finkel T, Holbrook NJ. Oxidants, oxidative stress and the biology of ageing. Nature. 2000 NOV 9; 408(6809): 239-247. & 1 & 0.07 & 6025 & 430.36 \\
\hline 3 & Harman D. Aging - a theory based on free-radical and radiation-chemistry. Journals of Gerontology. 1956; 11(3): 298-300. & 8 & 0.14 & 5430 & 93.62 \\
\hline 4 & $\begin{array}{l}\text { Dimri GP, et al. A biomarker that identifies senescent human-cells in culture and in aging skin in-vivo. Proceedings of The } \\
\text { National Academy of Sciences of The United States of America. } 1995 \text { SEP 26; 92(20): 9363-9367. }\end{array}$ & 6 & 0.32 & 4903 & 258.05 \\
\hline 5 & $\begin{array}{l}\text { Hall EO. The Deformation and ageing of mild Steel .3. Discussion of results proceedings of the Physical Society of London } \\
\text { Section B. } 1951 ; 64(381): 747-753\end{array}$ & 0 & 0.00 & 4723 & 74.97 \\
\hline 6 & $\begin{array}{l}\text { Ames BN, Shigenaga MK, Hagen TM. Oxidants, antioxidants, and the degenerative diseases of aging. Proceedings of the } \\
\text { National Academy of Sciences of The United States of America. } 1993 \text { Sep 1; 90(17): 7915-7922 }\end{array}$ & 3 & 0.14 & 4638 & 220.86 \\
\hline 7 & Lopez-Otin C, Blasco MA, Partridge L, Serrano M, Kroemer G. The hallmarks of aging cell. 2013 Jun 6; 153(6): 1194-1217 & 0 & 0.00 & 4489 & 4489.00 \\
\hline 8 & $\begin{array}{l}\text { Albert MS, DeKosky ST, Dickson D, Dubois B, Feldman HH, et al. The diagnosis of mild cognitive impairment due to } \\
\text { Alzheimer's disease: Recommendations from the National Institute on Aging-Alzheimer's Association workgroups on } \\
\text { diagnostic guidelines for Alzheimer's disease. Alzheimers \& Dementia. } 2011 \text { May; } 7(3): 270-279\end{array}$ & 4 & 1.33 & 4338 & 1446.00 \\
\hline 9 & $\begin{array}{l}\text { Harley CB, Futcher AB, Greider CW. Telomeres shorten during aging of human fibroblasts. Nature. } 1990 \text { May 31; 345(6274): } \\
458-460\end{array}$ & 5 & 0.21 & 4142 & 172.58 \\
\hline 10 & $\begin{array}{l}\text { Sperling RA, Aisen PS, Beckett LA, Bennett DA, Craft S, et al. Toward defining the preclinical stages of Alzheimer's disease: } \\
\text { Recommendations from the National Institute on Aging-Alzheimer's Association workgroups on diagnostic guidelines for } \\
\text { Alzheimer's disease Alzheimers \& Dementia. 2011 May; } 7(3): 280-292\end{array}$ & 4 & 1.33 & 3335 & 1111.67 \\
\hline 11 & $\begin{array}{c}\text { Good CD, Johnsrude IS, Ashburner J, Henson RNA, Friston KJ, et al. A voxel-based morphometric study of ageing in } 465 \\
\text { normal adult human brains. Neuroimage. } 2001 \mathrm{Jul} ; 14(1): 21-36\end{array}$ & 4 & 0.31 & 3296 & 253.54 \\
\hline 12 & $\begin{array}{l}\text { Feldman HA, Goldstein I, Hatzichristou DG, Krane RJ, Mckinlay JB. Impotence and its medical and psychosocial correlates - } \\
\text { Results of the Massachusetts male aging Study. Journal of Urology. } 1994 \text { Jan; 151(1): 54-61 }\end{array}$ & 1 & 0.05 & 3177 & 158.85 \\
\hline 13 & Beckman KB, Ames BN. The free radical theory of aging matures. Physiological Reviews. 1998 APR; 78(2): 547-581 & 2 & 0.13 & 2684 & 167.75 \\
\hline 14 & $\begin{array}{l}\text { Zoncu R, Efeyan A, Sabatini DM. mTOR: from growth signal integration to cancer, diabetes and ageing. Nature Reviews } \\
\text { Molecular Cell Biology. } 2011 \text { Jan; 12(1): 21-35 }\end{array}$ & 0 & 0.00 & 2640 & 880.00 \\
\hline 15 & Balaban RS, Nemoto S, Finkel T. Mitochondria, oxidants, and aging Cell. 2005 FEB 25; 120(4): 483-495 & 1 & 0.11 & 2630 & 292.22 \\
\hline 16 & $\begin{array}{l}\text { Berlett BS, Stadtman ER. Protein oxidation in aging, disease, and oxidative stress. Journal of Biological Chemistry. } 1997 \text { Aug } \\
\qquad 15 ; 272(33): 20313-20316\end{array}$ & 1 & 0.06 & 2418 & 142.24 \\
\hline 17 & $\begin{array}{l}\text { Greicius MD, Srivastava G, Reiss AL, Menon V. Default-mode network activity distinguishes Alzheimer's disease from healthy } \\
\text { aging: Evidence from functional MRI Proceedings of The National Academy of Sciences of The United States of America. } \\
\qquad 2004 \text { Mar 30;101(13): 4637-4642 }\end{array}$ & 0 & 0.00 & 2407 & 240.70 \\
\hline 18 & Sohal RS, Weindruch R. Oxidative stress, caloric restriction, and aging Science. 1996 Jul 5; 273(5271): 59-63 & 6 & 0.33 & 2318 & 128.78 \\
\hline 19 & $\begin{array}{c}\text { Fazekas F, Chawluk JB, Alavi A, Hurtig HI, Zimmerman RA. MR. Signal abnormalities at 1.5-T in Alzheimer dementia and } \\
\text { normal aging. American Journal of Roentgenology. } 1987 \text { Aug; 149(2): 351-356 }\end{array}$ & 0 & 0.00 & 2292 & 84.89 \\
\hline 20 & $\begin{array}{c}\text { Kuroo M, Matsumura Y, Aizawa } \mathrm{H} \text {, Kawaguchi } \mathrm{H} \text {, Suga T, et al. Mutation of the mouse klotho gene leads to a syndrome } \\
\text { resembling ageing Nature. } 1997 \text { Nov } 6 ; 390(6655): 45-51\end{array}$ & 1 & 0.06 & 2193 & 129.00 \\
\hline 21 & Fearnley JM, Lees AJ. Aging and Parkinsons-disease - Substantia-Nigra Regional Selectivity Brain. 1991 Oct; 114: $2283-2301$. & 0 & 0.00 & 2153 & 93.61 \\
\hline 22 & $\begin{array}{l}\text { Wallace DC. A mitochondrial paradigm of metabolic and degenerative diseases, aging, and cancer: A dawn for evolutionary } \\
\text { medicine. Annual Review of Genetics. 2005; 39: 359-407 }\end{array}$ & 2 & 0.22 & 2126 & 236.22 \\
\hline
\end{tabular}


Table 2 (continued). Top 100 most cited pulications in aging research

\begin{tabular}{|c|c|c|c|c|c|}
\hline Rank & Study reference & $\begin{array}{l}\text { Local } \\
\text { citations }\end{array}$ & $\begin{array}{l}\text { Per } \\
\text { year }\end{array}$ & $\begin{array}{c}\text { Global } \\
\text { citations }\end{array}$ & $\begin{array}{l}\text { Per } \\
\text { year }\end{array}$ \\
\hline 23 & $\begin{array}{l}\text { Brenner BM, Meyer TW, Hostetter TH. Dietary-protein intake and the progressive nature of kidney-disease - The role of } \\
\text { hemodynamically mediated glomerular injury in the pathogenesis of progressive glomerular sclerosis in aging, Renal } \\
\text { Ablation, and Intrinsic Renal-Disease. New England Journal of Medicine. 1982; 307(11):652-659 }\end{array}$ & 0 & 0.00 & 2101 & 65.66 \\
\hline 24 & $\begin{array}{c}\text { Franceschi C, Bonafe M, Valensin S, Olivieri F, De Luca M, et al. Inflamm-aging - An evolutionary perspective on } \\
\text { immunosenescence Molecular and Cellular Gerontology. 2000; 908: 244-254 }\end{array}$ & 1 & 0.07 & 2051 & 146.50 \\
\hline 25 & $\begin{array}{l}\text { Ames BN, Cathcart R, Schwiers E, Hochstein P. Uric-acid provides an antioxidant defense in humans against oxidant- } \\
\text { caused and radical-caused aging and cancer - A hypothesis. Proceedings of The National Academy of Sciences of The } \\
\text { United States of America-Biological Sciences. 1981; 78(11): 6858-6862 }\end{array}$ & 1 & 0.03 & 2020 & 61.21 \\
\hline 26 & $\begin{array}{l}\text { Cadenas E, Davies KJA. Mitochondrial free radical generation, oxidative stress, and aging. Free Radical Biology and } \\
\text { Medicine. } 2000 \text { Aug; } 29(3-4): 222-230\end{array}$ & 1 & 0.07 & 1933 & 138.07 \\
\hline 27 & $\begin{array}{c}\text { Vetter J, Novak P, Wagner MR, Veit C, Moller KC, et al. Ageing mechanisms in lithium-ion batteries. Journal of Power } \\
\text { Sources. } 2005 \text { Sep 9; 147(1-2): 269-281 }\end{array}$ & 0 & 0.00 & 1915 & 212.78 \\
\hline 28 & Rowe JW, Kahn RL. Successful aging. Gerontologist. 1997 AUG; 37(4): 433-440 & 0 & 0.00 & 1808 & 106.35 \\
\hline 29 & Fries JF. Aging, natural death, and the compression of morbidity. New England Journal of Medicine. 1980; 303(3): 130-135 & 2 & 0.06 & 1788 & 52.59 \\
\hline 30 & $\begin{array}{l}\text { Christensen K, Doblhammer G, Rau R, Vaupel JW. Ageing populations: the challenges ahead. Lancet. } 2009 \text { Oct 3; } \\
\text { 374(9696): 1196-1208 }\end{array}$ & 0 & 0.00 & 1771 & 354.20 \\
\hline 31 & $\begin{array}{l}\text { Wardlaw JM, Smith EE, Biessels GJ, Cordonnier C, Fazekas F, et al. Neuroimaging standards for research into small vessel } \\
\text { disease and its contribution to ageing and neurodegeneration. Lancet Neurology. } 2013 \text { Aug; 12(8): 822-838 }\end{array}$ & 0 & 0.00 & 1766 & 1766.00 \\
\hline 32 & $\begin{array}{l}\text { Knudson RJ, Lebowitz MD, Holberg CJ, Burrows B. Changes in the normal maximal expiratory flow-volume curve with } \\
\text { growth and aging. American Review of Respiratory Disease. 1983; 127(6): 725-734 }\end{array}$ & 0 & 0.00 & 1734 & 55.94 \\
\hline 33 & Stadtman ER. Protein oxidation and aging. Science. 1992 Aug 28; 257(5074): 1220-1224 & 3 & 0.14 & 1704 & 77.45 \\
\hline 34 & $\begin{array}{c}\text { Sapolsky RM, Krey LC, Mcewen BS. The neuroendocrinology of stress and aging - The glucocorticoid cascade hypothesis. } \\
\text { Endocrine Reviews. } 1986 \text { Aug; 7(3): 284-301 }\end{array}$ & 1 & 0.04 & 1689 & 60.32 \\
\hline 35 & Rowe JW, Kahn RL. Human aging - Usual and successful. Science. 1987 Jul 10; 237(4811): 143-149 & 1 & 0.04 & 1671 & 61.89 \\
\hline 36 & $\begin{array}{l}50 \text { Harman SM, Metter EJ, Tobin JD, Pearson J, Blackman MR. Longitudinal effects of aging on serum total and free } \\
\text { testosterone levels in healthy men. Journal of Clinical Endocrinology \& Metabolism. } 2001 \text { Feb; 86(2): 724-731 }\end{array}$ & 1 & 0.08 & 1663 & 127.92 \\
\hline 37 & $\begin{array}{l}\text { Trifunovic A, Wredenberg A, Falkenberg M, Spelbrink JN, Rovio AT, et al. Premature ageing in mice expressing defective } \\
\text { mitochondrial DNA polymerase. Nature } 2004 \text { May } 27 ; 429(6990): 417-423\end{array}$ & 6 & 0.60 & 1659 & 165.90 \\
\hline 38 & $\begin{array}{l}\text { Shigenaga MK, Hagen TM, Ames BN. Oxidative damage and mitochondrial decay in aging. Proceedings of The National } \\
\text { Academy of Sciences of The United States of America. } 1994 \text { Nov 8; 91(23): 10771-10778 }\end{array}$ & 2 & 0.10 & 1646 & 82.30 \\
\hline 39 & $\begin{array}{l}\text { Cottrell AH, Bilby BA. Dislocation theory of yielding and strain ageing of iron. Proceedings of The Physical Society of } \\
\text { London Section A. 1949;62(349): 49-62 }\end{array}$ & 1 & 0.02 & 1630 & 25.08 \\
\hline 40 & $\begin{array}{c}\text { Lakatta EG, Levy D. Arterial and cardiac aging: Major shareholders in cardiovascular disease enterprises Part I: Aging } \\
\text { arteries: A "set up" for vascular disease. Circulation. } 2003 \text { Jan 7; 107(1): 139-146 }\end{array}$ & 0 & 0.00 & 1613 & 146.64 \\
\hline 41 & $\begin{array}{l}\text { Huttenlocher PR. Synaptic density in human frontal-cortex - Developmental-changes and effects of aging. Brain } \\
\text { Research. 1979;163(2): 195-205 }\end{array}$ & 1 & 0.03 & 1612 & 46.06 \\
\hline 42 & $\begin{array}{l}\text { Raz N, Lindenberger U, Rodrigue KM, Kennedy KM, Head D, et al. Regional brain changes in aging healthy adults: General } \\
\text { trends, individual differences and modifiers. Cerebral Cortex. } 2005 \text { Nov; 15(11): 1676-1689 }\end{array}$ & 1 & 0.11 & 1562 & 173.56 \\
\hline 43 & $\begin{array}{l}\text { Campisi J. Senescent cells, tumor suppression, and organismal aging: Good citizens, bad neighbors. Cell. } 2005 \text { Feb 25; } \\
\qquad 120(4): 513-522\end{array}$ & 1 & 0.11 & 1549 & 172.11 \\
\hline 44 & Kenyon CJ. The genetics of ageing. Nature. 2010 Mar 25; 464(7288): 504-512 & 3 & 0.75 & 1549 & 387.25 \\
\hline 45 & $\begin{array}{c}\text { Baker DJ, Wijshake T, Tchkonia T, LeBrasseur NK, Childs BG, et al. Clearance of p16(Ink4a)-positive senescent cells delays } \\
\text { ageing-associated disorders. Nature. } 2011 \text { Nov 10;479(7372): 232-U112 }\end{array}$ & 2 & 0.67 & 1486 & 495.33 \\
\hline 46 & $\begin{array}{c}\text { Harman D. The aging process. Proceedings of The National Academy of Sciences of The United States of America- } \\
\text { Biological Sciences. 1981; 78(11): 7124-7128 }\end{array}$ & 3 & 0.09 & 1481 & 44.88 \\
\hline 47 & $\begin{array}{c}\text { Hastie ND, Dempster M, Dunlop MG, Thompson AM, Green DK, et al. Telomere reduction in human colorectal-carcinoma } \\
\text { and with aging. Nature. } 1990 \text { Aug } 30 ; 346(6287): 866-868\end{array}$ & 1 & 0.04 & 1412 & 58.83 \\
\hline 48 & $\begin{array}{l}\text { West RL. An application of prefrontal cortex function theory to cognitive aging. Psychological Bulletin. } 1996 \text { Sep; 120(2): } \\
\qquad 272-292\end{array}$ & 3 & 0.17 & 1369 & 76.06 \\
\hline 49 & $\begin{array}{l}\text { Wood JG, Rogina B, Lavu S, Howitz K, Helfand SL, et al. Sirtuin activators mimic caloric restriction and delay ageing in } \\
\text { metazoans. Nature. } 2004 \text { Aug } 5 ; 430(7000): 686-689\end{array}$ & 1 & 0.10 & 1353 & 135.30 \\
\hline 50 & $\begin{array}{l}\text { Savill JS, Wyllie AH, Henson JE, Walport MJ, Henson PM, et al. Macrophage phagocytosis of aging neutrophils in } \\
\text { inflammation - Programmed cell-death in the neutrophil leads to its recognition by macrophages. Journal of Clinical }\end{array}$ & 0 & 0.00 & 1342 & 53.68 \\
\hline
\end{tabular}
Investigation. 1989 Mar; 83(3): 865-875

Goodpaster BH, Park SW, Harris TB, Kritchevsky SB, Nevitt M, et al. The loss of skeletal muscle strength, mass, and quality

51 in older adults: The health, aging and body composition study. Journals of Gerontology Series A-Biological Sciences and $\quad 0 \quad 0.00 \quad 1339 \quad 167.38$ Medical Sciences. 2006 Oct; 61(10): 1059-1064

\begin{tabular}{|c|c|c|c|c|c|}
\hline 52 & $\begin{array}{l}\text { Poeggeler B, Reiter RJ, Tan DX, Chen LD, Manchester LC. Melatonin, hydroxyl radical-mediated oxidative damage, and } \\
\text { aging - A hypothesis. Journal of Pineal Research. } 1993 \text { May; 14(4): 151-168 }\end{array}$ & 0 & 0.00 & 1330 & 63.33 \\
\hline 53 & $\begin{array}{c}\text { Parfitt AM, Mathews CHE, Villanueva AR, Kleerekoper M, Frame B, et al. Relationships between surface, volume, and } \\
\text { thickness of Iliac Trabecular bone in aging and in osteoporosis - Implications for the microanatomic and cellular } \\
\text { mechanisms of bone loss. Journal of Clinical Investigation. 1983; 72(4): 1396-1409 }\end{array}$ & 0 & 0.00 & 1311 & 42.29 \\
\hline 54 & $\begin{array}{l}\text { Lexell J, Taylor CC, Sjostrom M. What is the cause of the aging atrophy - total number, size and proportion of different } \\
\text { fiber types studied in whole vastus lateralis muscle from 15-year-old to 83-year-old men. Journal of the Neurological } \\
\text { Sciences. } 1988 \text { Apr; 84(2-3): 275-294 }\end{array}$ & 2 & 0.08 & 1310 & 50.38 \\
\hline 55 & $\begin{array}{l}\text { Kujoth GC, Hiona A, Pugh TD, Someya S, Panzer K, et al. Mitochondrial DNA mutations, oxidative stress, and apoptosis in } \\
\text { mammalian aging. Science. } 2005 \text { Jul 15; 309(5733): 481-484 }\end{array}$ & 3 & 0.33 & 1304 & 144.89 \\
\hline 56 & Chan DC. Mitochondria: Dynamic organelles in disease, aging, and development. Cell. 2006 Jun 30; 125(7): 1241-1252 & 0 & 0.00 & 1250 & 156.25 \\
\hline 57 & $\begin{array}{l}\text { Goldberger AL, Amaral LAN, Hausdorff JM, Ivanov PC, Peng CK, et al. Fractal dynamics in physiology: Alterations with } \\
\text { disease and aging. Proceedings of The National Academy of Sciences of The United States of America. } 2002 \text { Feb 19; } 99 \text { : } \\
2466-2472\end{array}$ & 0 & 0.00 & 1248 & 104.00 \\
\hline 58 & $\begin{array}{l}\text { Park DC, Reuter-Lorenz P. The adaptive brain: Aging and neurocognitive scaffolding. Annual Review of Psychology. 2009; } \\
60: 173-196\end{array}$ & 0 & 0.00 & 1211 & 242.20 \\
\hline 59 & $\begin{array}{l}\text { Cabeza R, Anderson ND, Locantore JK, Mclntosh AR. Aging gracefully: Compensatory brain activity in high-performing } \\
\text { older adults. Neuroimage. } 2002 \text { Nov; } 17(3): 1394-1402\end{array}$ & 2 & 0.17 & 1191 & 99.25 \\
\hline
\end{tabular}


Table 2 (continued). Top 100 most-cited studies in aging research

\begin{tabular}{|c|c|c|c|c|c|}
\hline Rank & Study reference & $\begin{array}{c}\text { Local } \\
\text { citations }\end{array}$ & $\begin{array}{l}\text { Per } \\
\text { year }\end{array}$ & $\begin{array}{l}\text { Global } \\
\text { citations }\end{array}$ & $\begin{array}{l}\text { Per } \\
\text { year }\end{array}$ \\
\hline 60 & $\begin{array}{l}\text { Lu T, Pan Y, Kao SY, Li C, Kohane I, et al. Gene regulation and DNA damage in the ageing human brain. Nature. } 2004 \text { Jun } 24 ; \\
429(6994): 883-891\end{array}$ & 0 & 0.00 & 1189 & 118.90 \\
\hline 61 & $\begin{array}{l}\text { Price JL, Morris JC. Tangles and plaques in nondemented aging and "preclinical” Alzheimer's disease. Annals of Neurology. } \\
1999 \text { Mar; 45(3): 358-368 }\end{array}$ & 1 & 0.07 & 1174 & 78.27 \\
\hline 62 & $\begin{array}{l}\text { Zecca L, Youdim MBH, Riederer P, Connor JR, Crichton RR. Iron, brain ageing and neurodegenerative disorders. Nature } \\
\text { Reviews Neuroscience. } 2004 \text { Nov; 5(11): 863-873 }\end{array}$ & 0 & 0.00 & 1171 & 117.10 \\
\hline 63 & Rubinsztein DC, Marino G, Kroemer G. Autophagy and aging. Cell. 2011 Sep 2; 146(5): 682-695 & 1 & 0.33 & 1171 & 390.33 \\
\hline 64 & $\begin{array}{l}\text { Hedden T, Gabrieli JDE. Insights into the ageing mind: A view from cognitive neuroscience. Nature Reviews Neuroscience. } \\
2004 \text { Feb; 5(2): 87-U12 }\end{array}$ & 1 & 0.10 & 1168 & 116.80 \\
\hline 65 & $\begin{array}{l}\text { Drachman DA, Leavitt J. Human memory and cholinergic system - Relationship to aging. Archives of Neurology. 1974; 30(2): } \\
\text { 113-121 }\end{array}$ & 0 & 0.00 & 1167 & 29.18 \\
\hline 66 & $\begin{array}{l}\text { Lee CK, Klopp RG, Weindruch R, Prolla TA. Gene expression profile of aging and its retardation by caloric restriction. } \\
\text { Science. } 1999 \text { Aug 27; 285(5432): 1390-1393 }\end{array}$ & 2 & 0.13 & 1157 & 77.13 \\
\hline 67 & Beal MF. Aging, Energy, and oxidative stress in neurodegenerative diseases. Annals of Neurology. 1995 Sep; 38(3): 357-366 & 1 & 0.05 & 38 & 59.89 \\
\hline 68 & Kirkwood TBL. Evolution of aging. Nature. 1977; 270(5635): 301-304 & 1 & 0.03 & 1132 & 30.59 \\
\hline 69 & Stern Y. Cognitive reserve in ageing and Alzheimer's disease. Lancet Neurology. 2012 Nov; 11(11): 1 & 0 & 0.00 & 1118 & 559.00 \\
\hline 70 & Campisi J. Aging, Cellular Senescence, and Cancer. Annual Review of Physiology, 2013; 75: 685-705 & 0 & 0.00 & 1116 & 1116.00 \\
\hline 71 & $\begin{array}{l}\text { Wallace DC. Mitochondrial genetics - A paradigm for aging and degenerative diseases. Science. } 1992 \text { May 1; 256(5057): 628- } \\
632\end{array}$ & 3 & 0.14 & 1104 & 50.18 \\
\hline 72 & $\begin{array}{l}\text { Hoeijmakers JHJ. Molecular origins of cancer DNA damage, aging, and cancer. New England Journal of Medicine. } 2009 \text { Oct } \\
\qquad 8 ; 361(15): 1475-1485\end{array}$ & 1 & 0.20 & 1102 & 220.40 \\
\hline 73 & $\begin{array}{r}\text { Robinson AL, Donahue NM, Shrivastava MK, Weitkamp EA, } \\
\text { emissions and photochemical aging. Sci }\end{array}$ & 0 & 0.00 & 1100 & 157.14 \\
\hline 74 & $\begin{array}{r}\text { Kurosu H, Yamamoto M, Clark JD, Pastor JV, Nandi A, et al. Suppression of a } \\
2005 \text { Sep 16; 309(5742): 1829-18 }\end{array}$ & 0 & 0.00 & 1097 & 121.89 \\
\hline 75 & $\begin{array}{l}\text { Franceschi C, Capri M, Monti D, Giunta S, Olivieri F, et al. Inflar } \\
\text { aging and longevity emerged from studies in humans. Mecha }\end{array}$ & 0 & 0.00 & 1084 & 154.86 \\
\hline 76 & $\begin{array}{r}\text { Salat DH, Buckner RL, Snyder AZ, Greve DN, Desikan RSR, e } \\
2004 \text { Jul; } 1\end{array}$ & 1 & 0.10 & 1076 & 107.60 \\
\hline 77 & $\begin{array}{l}\text { Feldman HA, Longcope C, Derby CA, Johannes CB, Araujo AB, et al. Age trends in the level of serum testosterone and other } \\
\text { hormones in middle-aged men: Longitudinal results from the Massachusetts Male Aging Study. Journal of Clinical } \\
\text { Endocrinology \& Metabolism. 2002 Feb; 87(2):589-598 }\end{array}$ & 0 & 0.00 & 5 & 89.58 \\
\hline 78 & $\begin{array}{c}\text { Riggs BL, Wahner HW, Dunn WL, Mazess RB, Offord KP, et al. Differential changes in bone-mineral density of the } \\
\text { appendicular and axial skeleton with aging - Relationship to spinal osteoporosis. Journal of Clinical Investigation. 1981; } \\
67(2): 328-335\end{array}$ & 0 & 0.00 & 72 & 32.48 \\
\hline 79 & $\begin{array}{l}\text { Smith CD, Carney JM, Starkereed PE, Oliver CN, Stadtman ER, et al. Excess brain protein oxidation and enzyme dysfunction } \\
\text { in normal aging and in Alzheimer-disease. Proceedings of The National Academy of Sciences of The United States of } \\
\text { America. } 1991 \mathrm{Dec} ; 88(23): 10540-10543\end{array}$ & 4 & 0.17 & 1072 & 46.61 \\
\hline 80 & $\begin{array}{r}\text { Colcombe SJ, Erickson KI, Scalf PE, Kim JS, Prakash R, } \\
\text { humans. Journals of Gerontology Series A-Biological }\end{array}$ & 0 & 0.00 & 1068 & 133.50 \\
\hline 81 & $\begin{array}{l}\text { Hyman BT, Phelps CH, Beach TG, Bigio EH, Cairns NJ, et al. National Institute on Aging-Alzheimer's Association guidelines } \\
\text { for the neuropathologic assessment of Alzheimer's disease. Alzheimers \& Dementia. } 2012 \text { Jan; 8(1): 1-13 }\end{array}$ & 0 & 0.00 & 1067 & 533.50 \\
\hline 82 & Stadtman ER. Protein oxidation and aging. Free Radical Research. 2006 Dec; 40(12): 1250-1258 & 3 & 0.38 & 1063 & 132.88 \\
\hline 83 & $\begin{array}{l}\text { Tyner SD, Venkatachalam S, Choi J, Jones S, Ghebranious N, et al. p53 mutant mice that display early ageing-a } \\
\text { phenotypes. Nature. } 2002 \text { Jan 3; 415(6867): 45-53 }\end{array}$ & 3 & 0.25 & 1062 & 88.50 \\
\hline 84 & $\begin{array}{l}\text { Montine TJ, Phelps CH, Beach TG, Bigio EH, Cairns NJ, et al. National Institute on Aging-Alzheimer's Association guidelines } \\
\text { for the neuropathologic assessment of Alzheimer's disease: a practical approach. Acta Neuropathologica. } 2012 \text { Jan; 123(1): } \\
1-11\end{array}$ & 0 & 0.00 & 1061 & 530.50 \\
\hline 85 & Collado M, Blasco MA, Serrano M. Cellular senescence in cancer and aging. Cell. 2007 Jul 27; 130(2): 223-233 & 1 & 0.14 & 1049 & 149.86 \\
\hline 86 & $\begin{array}{c}\text { Hannum G, Guinney J, Zhao L, Zhang L, Hughes G, et al. Genome-wide methylation profiles reveal quantitative vien } \\
\text { human aging rates. Molecular Cell. } 2013 \text { Jan 24; 49(2): 359-367 }\end{array}$ & 0 & 0.00 & 1048 & 1048.00 \\
\hline 87 & $\begin{array}{l}\text { Lupien SJ, de Leon M, de Santi S, Convit A, Tarshish C, et al. Cortisol levels during human aging predict hippocampal } \\
\text { atrophy and memory deficits. Nature Neuroscience. } 1998 \text { May; 1(1):69-73 }\end{array}$ & 0 & 0.00 & 1044 & 65.25 \\
\hline 88 & $\begin{array}{l}\text { Marengoni A, Angleman S, Melis R, Mangialasche F, Karp A, et al. Aging with multimorbidity: A systematic review of the } \\
\text { literature. Ageing Research Reviews. } 2011 \text { Sep; 10(4): 430-439 }\end{array}$ & 0 & 0.00 & 1032 & 344.00 \\
\hline 89 & Sinclair DA, Guarente L. Extrachromosomal rDNA circles - A cause of aging in yeast. Cell. 1997 Dec26; 91(7): 1033-1042 & 2 & 0.12 & 1026 & 60.35 \\
\hline 90 & Brownlee M. Advanced protein glycosylation in diabetes and aging. Annual Review of Medicine. 1995; 46: 223-234 & 0 & 0.00 & 1017 & 53.53 \\
\hline 91 & Blasco MA. Telomeres and human disease: Ageing, cancer and beyond. Nature Reviews Genetics. 2005 Aug; 6(8): 611-622 & 1 & 0.11 & 1016 & 112.89 \\
\hline 92 & $\begin{array}{c}\text { Rudolph KL, Chang S, Lee HW, Blasco M, Gottlieb GJ, et al. Longevity, stress response, and cancer in aging telomerase- } \\
\text { deficient mice. Cell. } 1999 \text { Mar 5; 96(5): 701-712 }\end{array}$ & 3 & 0.20 & 1005 & 67.00 \\
\hline 93 & Doherty TJ. Aging and sarcopenia. Journal of Applied Physiology. 2003 Oct; 95(4): 1717-1727 & 1 & 0.09 & 1002 & 91.09 \\
\hline 94 & $\begin{array}{l}\text { Plassman BL, Langa KM, Fisher GG, Heeringa SG, Weir DR, et al. Prevalence of dementia in the United States: } \\
\text { demographics, and memory study. Neuroepidemiology. 2007; 29(1-2): 125-132 }\end{array}$ & 0 & 0.00 & 999 & 142.71 \\
\hline 95 & $\begin{array}{l}\text { Smith BD, Smith GL, Hurria A, Hortobagyi GN, Buchholz TA. Future of cancer incidence in the United States: Burdens upon } \\
\text { an aging, changing nation. Journal of Clinical Oncology. } 2009 \text { Jun 10;27(17): 2758-2765 }\end{array}$ & 0 & 0.00 & 997 & 199.40 \\
\hline 96 & $\begin{array}{l}\text { Mostoslavsky R, Chua KF, Lombard DB, Pang WW, Fischer MR, et al. Genomic instability and aging-like phenotype in the } \\
\text { absence of mammalian SIRT6. Cell. } 2006 \text { Jan 27; 124(2):315-329 }\end{array}$ & 1 & 0.13 & 995 & 124.38 \\
\hline 97 & $\begin{array}{c}\text { Fisher GJ, Datta SC, Talwar HS, Wang ZQ, Varani J, et al. Molecular basis of sun-induced premature skin ageing and retinoid } \\
\text { antagonism. Nature. } 1996 \text { Jan } 25 ; 379(6563): 335-339\end{array}$ & 0 & 0.00 & 985 & 54.72 \\
\hline 98 & Guarente L, Kenyon C. Genetic pathways that regulate ageing in model organisms. Nature. 2000 Nov 9; 408(6809): 255-262 & 1 & 0.07 & 984 & 70.29 \\
\hline 99 & $\begin{array}{l}\text { Alexander M. Aging, bioavailability, and overestimation of risk from environmental pollutants. Environmental Science \& } \\
\text { Technology. } 2000 \text { Oct } 15 ; 34(20): 4259-4265\end{array}$ & 0 & 0.00 & 982 & 70.14 \\
\hline 100 & 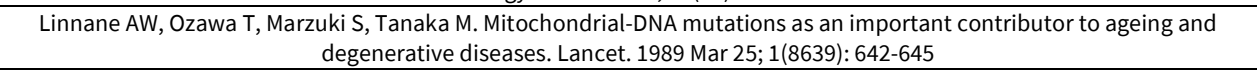 & 3 & 0.12 & 979 & 39.16 \\
\hline
\end{tabular}




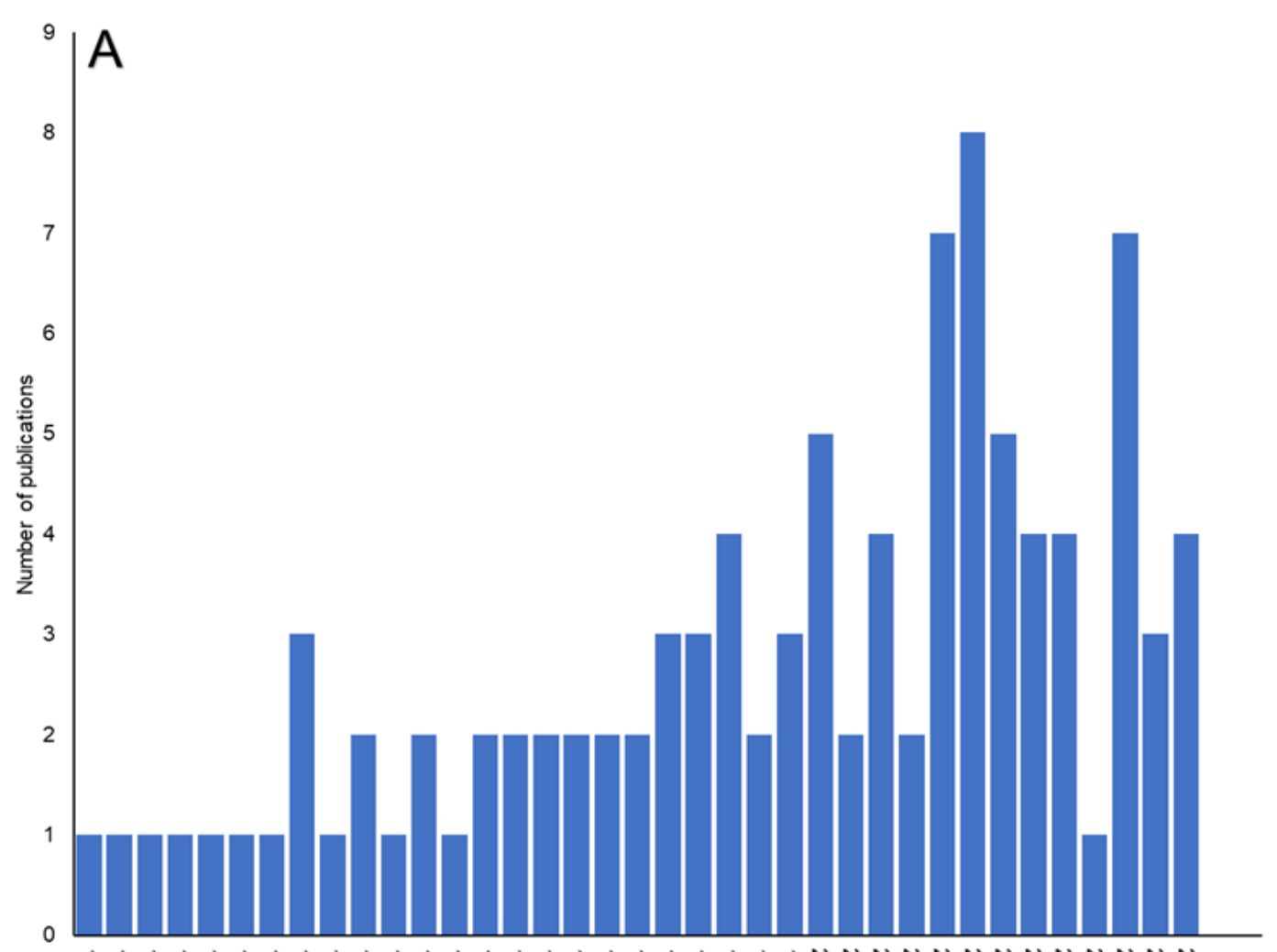

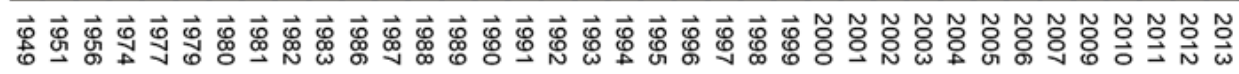

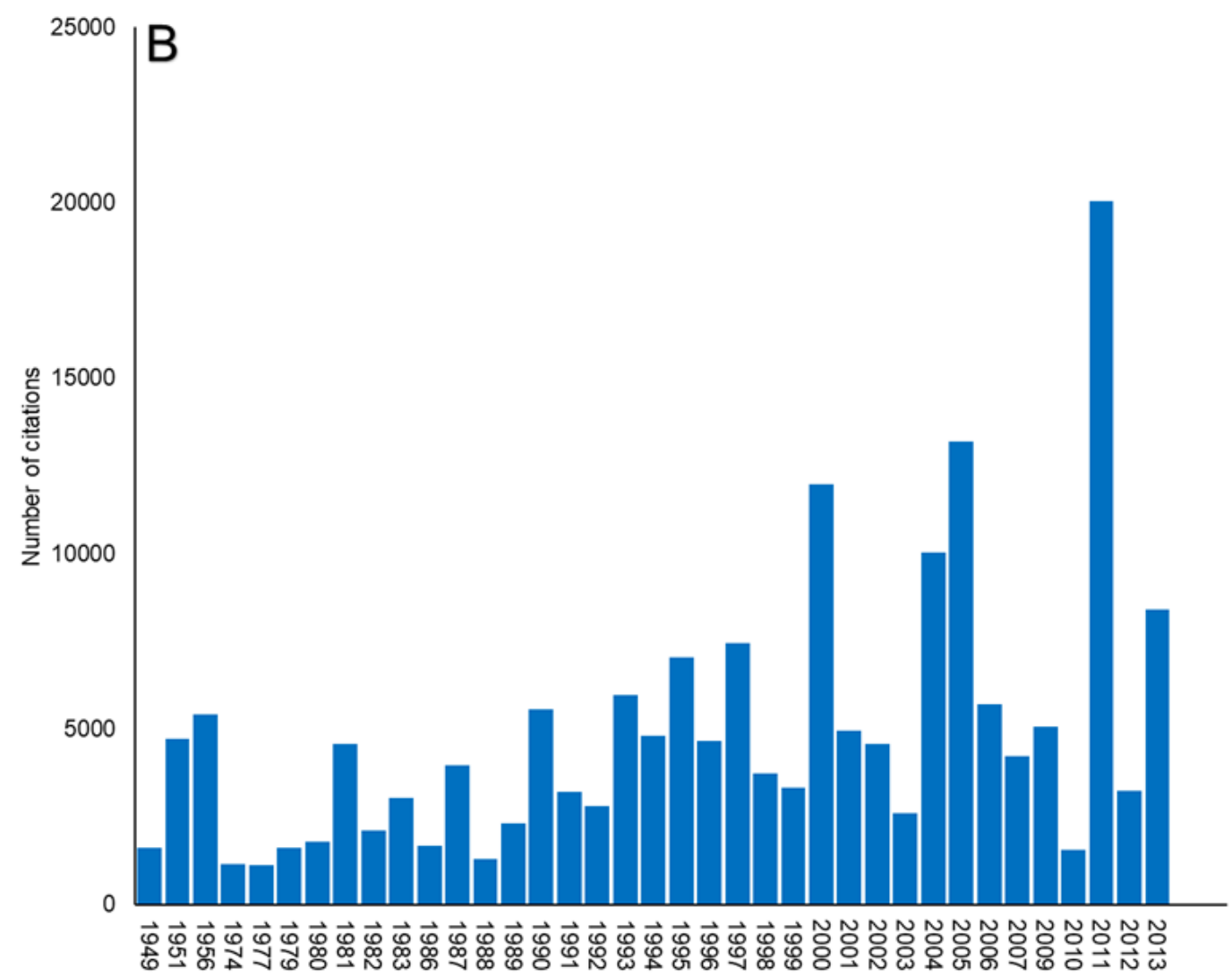

Figure 3. A) Year of publications (1949-2013) of the 100 most cited papers, B) Global citations of the 100 most cited publications

United States of America (USA) with 76 publications (Table 3). Aging ( $n=78)$, Ageing $(n=22)$, and Disease $(n=17)$ were the most frequently used keywords (Table 4). The most prolific author was Phelps $\mathrm{CH}(\mathrm{n}=5)$ (Table 5). The most active institute was Harvard University, USA ( $n=13)$ (Table 6). Nature was the most attractive journal ( $n=13)$ (Table 7$)$. 
Table 3. Country with at least 3 publications

\begin{tabular}{|c|c|c|c|c|}
\hline Country & Publications & Percent & LCS & GCS \\
\hline USA & 76 & 76 & 92 & 131441 \\
\hline UK & 10 & 10 & 17 & 27068 \\
\hline Germany & 9 & 9 & 4 & 15864 \\
\hline France & 6 & 6 & 5 & 13892 \\
\hline Netherlands & 6 & 6 & 7 & 12764 \\
\hline Canada & 5 & 5 & 7 & 11042 \\
\hline Italy & 5 & 5 & 1 & 7104 \\
\hline Japan & 5 & 5 & 11 & 8908 \\
\hline Spain & 4 & 4 & 5 & 7559 \\
\hline Sweden & 4 & 4 & 8 & 5767 \\
\hline
\end{tabular}

LCS: Total local citation score, GCS: Total global citation score

Table 4. The occurrence of a keyword at least 3 times

\begin{tabular}{|c|c|c|c|c|}
\hline Word & Occurrences & Percent & LCS & GCS \\
\hline Aging & 78 & 78 & 103 & 139053 \\
\hline Ageing & 22 & 22 & 28 & 41678 \\
\hline Disease & 17 & 17 & 19 & 35176 \\
\hline Human & 11 & 11 & 19 & 22500 \\
\hline Alzheimer & 10 & 10 & 17 & 23903 \\
\hline Cancer & 9 & 9 & 9 & 13071 \\
\hline Oxidative & 8 & 8 & 15 & 18112 \\
\hline Stress & 8 & 8 & 17 & 17830 \\
\hline Brain & 7 & 7 & 7 & 8464 \\
\hline Mitochondrial & 7 & 7 & 20 & 10751 \\
\hline Protein & 6 & 6 & 11 & 9375 \\
\hline Association & 5 & 5 & 12 & 15840 \\
\hline Diseases & 5 & 5 & 12 & 9985 \\
\hline Dna & 5 & 5 & 13 & 6233 \\
\hline Guidelines & 5 & 5 & 12 & 15840 \\
\hline Institute & 5 & 5 & 12 & 15840 \\
\hline National & 5 & 5 & 12 & 15840 \\
\hline Radical & 5 & 5 & 12 & 13397 \\
\hline Changes & 4 & 4 & 2 & 5980 \\
\hline Cognitive & 4 & 4 & 8 & 7993 \\
\hline Damage & 4 & 4 & 3 & 5267 \\
\hline Degenerative & 4 & 4 & 11 & 8847 \\
\hline Free & 4 & 4 & 12 & 11710 \\
\hline Mice & 4 & 4 & 12 & 4823 \\
\hline Normal & 4 & 4 & 8 & 8394 \\
\hline Oxidation & 4 & 4 & 11 & 6257 \\
\hline Theory & 4 & 4 & 14 & 11113 \\
\hline Adults & 3 & 3 & 3 & 4092 \\
\hline Caloric & 3 & 3 & 9 & 4828 \\
\hline Cells & 3 & 3 & 9 & 7938 \\
\hline Cellular & 3 & 3 & 1 & 3476 \\
\hline Cortex & 3 & 3 & 5 & 4057 \\
\hline Dementia & 3 & 3 & 4 & 9330 \\
\hline Diagnostic & 3 & 3 & 12 & 13712 \\
\hline Gene & 3 & 3 & 3 & 4539 \\
\hline Healthy & 3 & 3 & 2 & 5632 \\
\hline Humans & 3 & 3 & 1 & 4172 \\
\hline Hypothesis & 3 & 3 & 2 & 5039 \\
\hline Memory & 3 & 3 & 0 & 3210 \\
\hline Men & 3 & 3 & 3 & 4048 \\
\hline Oxidants & 3 & 3 & 5 & 13293 \\
\hline Recommendations & 3 & 3 & 12 & 13712 \\
\hline Restriction & 3 & 3 & 9 & 4828 \\
\hline Results & 3 & 3 & 1 & 8975 \\
\hline Senescent & 3 & 3 & 9 & 7938 \\
\hline Volume & 3 & 3 & 0 & 4113 \\
\hline Workgroups & 3 & 3 & 12 & 13712 \\
\hline
\end{tabular}


Table 5. The author with at least 3 publications

\begin{tabular}{|c|c|c|c|c|c|c|c|}
\hline Author & Publications & Percent & LCS & LCS/t & GCS & $\mathbf{G C S} / \mathbf{t}$ & LCR \\
\hline Phelps CH & 5 & 5 & 12 & 4 & 15840 & 5634.667 & 13 \\
\hline Ames BN & 4 & 4 & 8 & 0.39816 & 10988 & 532.1193 & 16 \\
\hline Carrillo MC & 4 & 4 & 12 & 4 & 14779 & 5104.167 & 10 \\
\hline Stadtman ER & 4 & 4 & 11 & 0.7441 & 6257 & 399.1735 & 4 \\
\hline Thies B & 4 & 4 & 12 & 4 & 14779 & 5104.167 & 10 \\
\hline Blasco MA & 3 & 3 & 2 & 0.253968 & 6554 & 4751.746 & 17 \\
\hline Campisi J & 3 & 3 & 7 & 0.426901 & 7568 & 1546.164 & 5 \\
\hline Guarente L & 3 & 3 & 4 & 0.314076 & 3005 & 255.0137 & 8 \\
\hline Hyman BT & 3 & 3 & 4 & 1.333333 & 8167 & 3077 & 9 \\
\hline Montine TJ & 3 & 3 & 4 & 1.333333 & 5463 & 2175.667 & 9 \\
\hline Morris JC & 3 & 3 & 6 & 1.5 & 8289 & 2198.867 & 4 \\
\hline Weindruch $\mathbf{R}$ & 3 & 3 & 11 & 0.8 & 4779 & 350.8 & 9 \\
\hline
\end{tabular}

LCS: Total local citation score, LCS/t: Total local citation score per year, GCS: Total global citation score, GCS/t: Total global citation score per year, LCR: Total local cited references.

Table 6. The institution with at least 3 publications

\begin{tabular}{|c|c|c|c|c|}
\hline Institution & Publications & Percent & LCS & GCS \\
\hline Harvard Univ & 13 & 13 & 15 & 23299 \\
\hline NIA & 9 & 9 & 14 & 26480 \\
\hline Washington Univ & 8 & 8 & 15 & 19652 \\
\hline Univ Calif San Diego & 6 & 6 & 8 & 11893 \\
\hline Johns Hopkins Univ & 5 & 5 & 12 & 14093 \\
\hline Mayo Clin & 5 & 5 & 10 & 13991 \\
\hline NHLBI & 5 & 5 & 9 & 12191 \\
\hline UCL & 5 & 5 & 12 & 19928 \\
\hline Univ Calif Berkeley & 5 & 5 & 14 & 14687 \\
\hline Univ Michigan & 5 & 5 & 1 & 6674 \\
\hline Alzheimers Assoc & 4 & 4 & 12 & 14779 \\
\hline MIT & 4 & 4 & 4 & 5645 \\
\hline Univ Calif San Francisco & 4 & 4 & 8 & 7207 \\
\hline Univ Tokyo & 4 & 4 & 8 & 7929 \\
\hline Univ Washington & 4 & 4 & 4 & 6538 \\
\hline Univ Wisconsin & 4 & 4 & 11 & 5851 \\
\hline Brigham \& Womens Hosp & 3 & 3 & 1 & 4285 \\
\hline Brown Univ & 3 & 3 & 8 & 6995 \\
\hline Northwestern Univ & 3 & 3 & 0 & 3295 \\
\hline Rush Univ & 3 & 3 & 4 & 5463 \\
\hline Univ Kentucky & 3 & 3 & 4 & 3200 \\
\hline Univ So Calif & 3 & 3 & 2 & 5001 \\
\hline Univ Texas & 3 & 3 & 3 & 3731 \\
\hline
\end{tabular}

LCS: Total local citation score, GCS: Total global citation score

Table 7. The 6 Journal with at least 3 publications

\begin{tabular}{cccccccc}
\hline Journal & Publications & Percent & LCS & LCS/t & GCS & GCS/t & LCR \\
\hline Nature & 13 & 13 & 25 & 2.845374 & 25171 & 2337.56 & 11 \\
\hline Cell & 9 & 9 & 10 & 1.14106 & 15164 & 5901.502 & 37 \\
\hline Science & 8 & 8 & 18 & 1.109764 & 11455 & 819.357 & 13 \\
\hline $\begin{array}{c}\text { Proceedings of the National Academy of } \\
\text { Sciences of the United States of America }\end{array}$ & 6 & 6 & 15 & 0.73256 & 15914 & 952.5185 & 7 \\
\hline Alzheimers \& Dementia & 4 & 4 & 12 & 4 & 14779 & 5104.167 & 10 \\
\hline Journal of Clinical Investigation & 3 & 3 & 0 & 0 & 3725 & 128.4552 & 0 \\
\hline New England Journal of Medicine & 3 & 3 & 3 & 0.258824 & 4991 & 338.6445 & 1 \\
\hline
\end{tabular}

LCS: Total local citation score, LCS/t: Total local citation score per year, GCS: Total global citation score, GCS/t: Total global citation score per year, LCR: Total local cited references. 

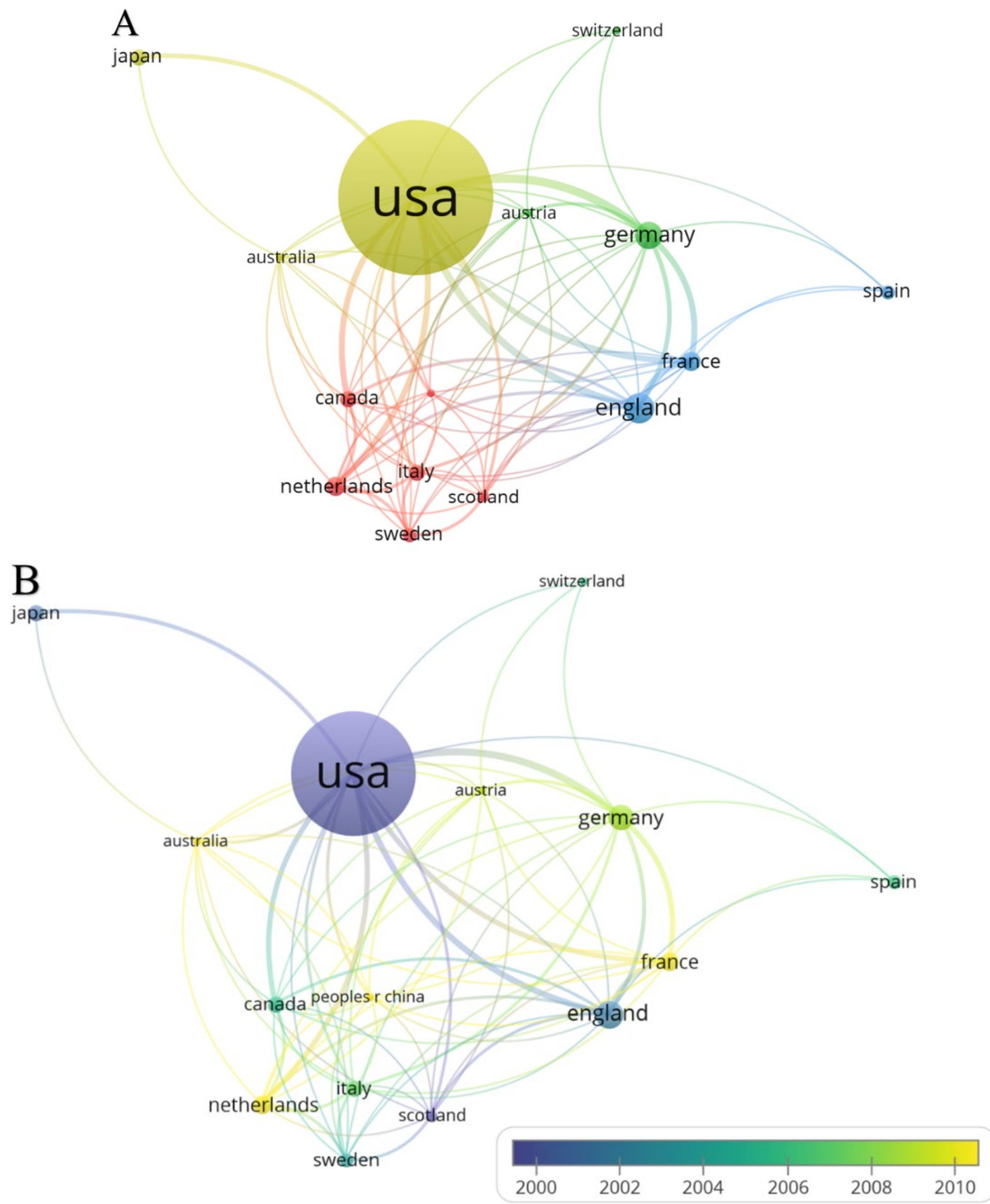

Figure 4. (A) Co-authorship and country network visualization mapping. (B) Overlay visualization mapping by time (year). There are four clusters formed; Red color designates cluster 1 (Canada, Italy, Netherlands, China, Scotland, Sweden), green color designates cluster 2 (Austria, Germany, Switzerland), blue color designates cluster 3 (England, France, Spain), and yellow color designates cluster 4 (Australia, Japan, USA)

\section{Co-authorship and Country}

The co-authorship and country mapping is presented in Figure 4. The minimum number of the document per country was set at 2. Of the 22 countries, 15 were included for visualization after network mapping. The USA had the highest total link strength (TLS) of 38, followed by England (TLS=24), and Germany (TLS=25).

\section{Co-occurrences and Author Keywords}

The minimum number of a keyword occurrence was fixed at 1 . Minimum items included in a cluster were fixed at 5. Based on TLS, aging and dementia were the most widely used author keywords (TLS=49), and (TLS=16) respectively as shown in Figure 5. 

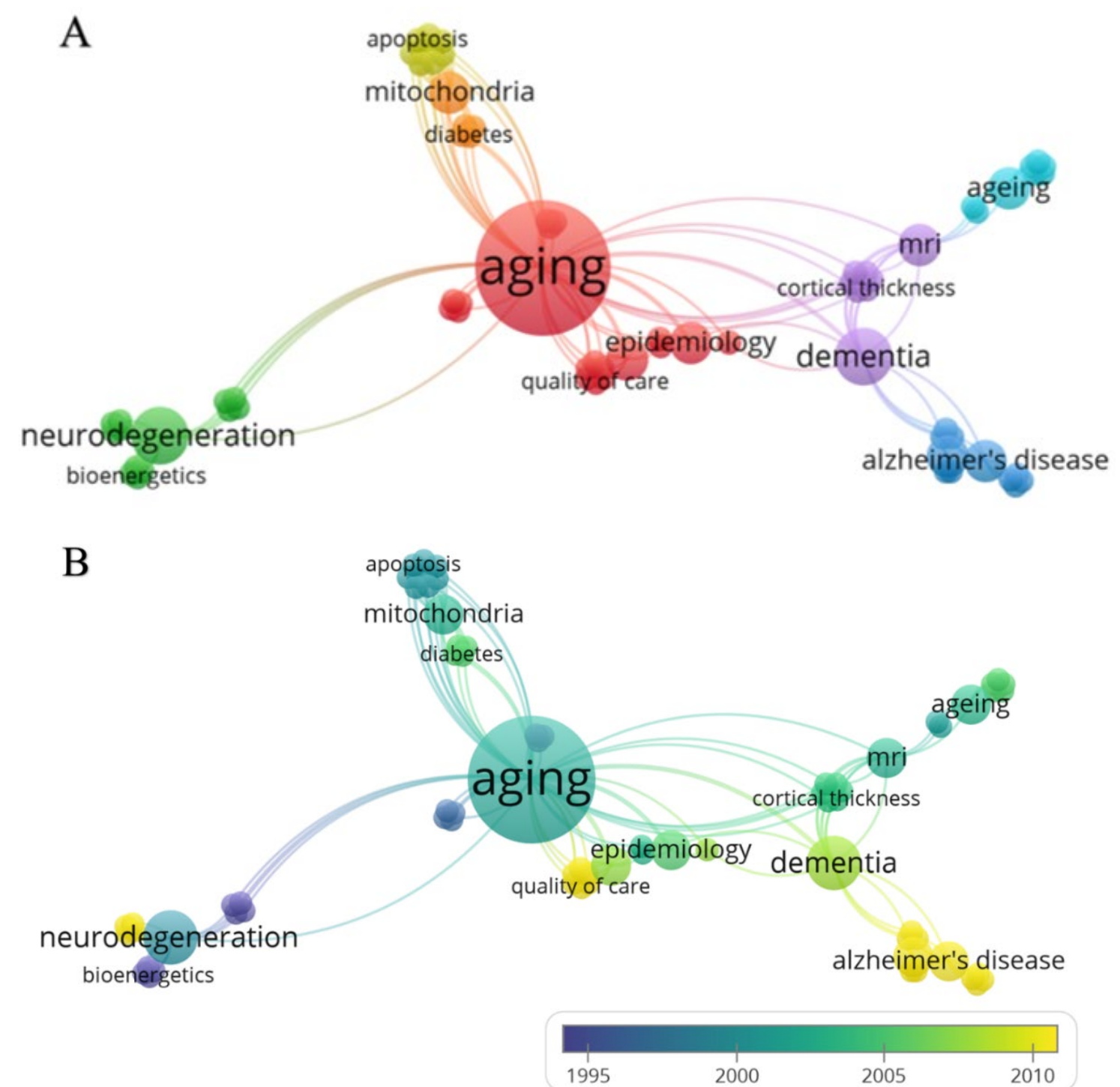

Figure 5. (A) Author keywords visualization mapping. (B) Overlay visualization by time (year). There are 7 clusters formed; cluster 1 red color (19 items), cluster 2 green color (13 items), cluster 3 blue color (11 items), cluster 4 yellow color (9 items), cluster 5 purple color (8 items), cluster 6 light blue (8 items), and cluster 7 orange color (5 items)

\section{DISCUSSION}

Bibliometric type studies are of great interest, providing an overview of the scientific published literature and other important parameters [22]. The number of bibliometric studies has been increased over the years [23]. This is the first comprehensive bibliometric analysis summarizing several features of the most influential studies on aging. Analysis of most cited studies on aging may be worthwhile to keep the young researchers and clinicians abreast of traditional knowledge. It may help clinicians, nutritionists and policymakers to decide based on results from influential previous studies.

Aging is an irreversible phenomenon that leaves multiple effects on the human body. Generally, it weakens muscles and all the body functions, leading to certain complications that ultimately burden the health system. In order to overview the research trends and most commonly addressed issues, the bibliometric is the most helpful strategy to reach the hot spot and analyze the research conducted in the field. By this, the researcher can easily identify the multiple studies on the same topic, select the best one, and summarize the best available evidence after critical analysis. This bibliometric study has selected 100 publications/papers out of 131,652 on aging published during the last century, i.e., from 1900-2021. During this period, the citation and publication pattern is not uniform. It keeps changing from year to year.

The top 100 papers were published in 52 different journals. Nature was the most frequent journal with 13 publications, followed by Cell $(n=9)$ and Science $(n=8)$. This trend depicts aging as a vast field with different dimensions that allow the authors to publish in well-reputed scientific journals. This study encompasses a wide variety of institutions, countries and authors involved in most cited publications. In this regard, Harvard University was on top, followed by NIA and Washington University, while the USA was the leading country, followed by United Kingdom (UK), Germany, and France. Among the most cited authors, Phelps $\mathrm{CH}$ was on top, which received 15840 citations.

All the included publications in this study were published in English, and 63\% were research articles while 29\% reviews, $4 \%$ proceeding papers, $3 \%$ were book chapters. This trend 
illustrates that English is a widely used language to exchange scientific findings, and a majority of the scientific results on aging are being published resulting from experimental work though the share of review and other articles are also countable. The most frequently used keywords and research areas linked with aging studies reflect the research focus.

More research is needed to be carried out in this field, and scientists, especially from developing countries, should be encouraged to conduct research and share the findings in peerreviewed journals. Moreover, researchers and clinicians need to use the evidence summaries in clinical practices and update and develop new summaries based on their practices to use these approaches as well.

\section{LIMITATIONS}

This study has several limitations; a) a single database (WoSCC) was utilized; b) The citations count was based on WoSCC; c) The use of other databases like like Scopus and Google Scholar may alter the citations count or publications frequency.

\section{CONCLUSION}

This study provides a detailed, comprehensive overview of aging research. The USA was ranked the most productive and active country. The finding from 100 most cited publications in aging research may help the researchers, policymakers, and funding agencies for future research directions and hotspots. Low- and middle-income countries need to be supported through funding and by collaborating with them to upgrade the technical skills of researchers and clinicians.

Author contributions: All authors have sufficiently contributed to the study, and agreed with the results and conclusions.

Funding: No funding source is reported for this study.

Declaration of interest: No conflict of interest is declared by authors.

\section{REFERENCES}

1. Kim Y, Nam HG, Valenzano DR. The short-lived African turquoise killifish: An emerging experimental model for ageing. Dis Model Mech 2016;9(2):115-29. https://doi.org/ 10.1242/dmm.023226 PMid:26839399 PMCid:PMC4770150

2. López-Otín C, Blasco MA, Partridge L, Serrano M, Kroemer GJC. The hallmarks of aging. Cell 2013;153(6):1194-217. https://doi.org/10.1016/j.cell.2013.05.039 PMid:23746838 PMCid:PMC3836174

3. Akushevich I, Kravchenko J, Ukraintseva S, Arbeev K, Yashin Al. Time trends of incidence of age-associated diseases in the US elderly population: Medicare-based analysis. Age Ageing 2013;42(4):494-500. https://doi.org/10.1093/ageing/aft032 PMid:23482353 PMCid:PMC3684110

4. Qian M, Liu BJTMoA. Advances in pharmacological interventions of aging in mice. Transl Med Aging 2019;3:116-20. https://doi.org/10.1016/j.tma.2019.11.002

5. Corona M, Hughes KA, Weaver DB, Robinson GE. Gene expression patterns associated with queen honey bee longevity. Mech Ageing Dev 2005;126(11):1230-8 https://doi.org/10.1016/j.mad.2005.07.004 PMid:16139867
6. Opfer JE, Siegler RS. Revisiting preschoolers' living things concept: A microgenetic analysis of conceptual change in basic biology. Cogn Psychol 2004;49(4):301-32. https://doi. org/10.1016/j.cogpsych.2004.01.002 PMid:15342257

7. Rushton JP, Jensen AR. Thirty years of research on race differences in cognitive ability. Psychol Public Policy Law 2005;11(2):235. https://doi.org/10.1037/1076-8971.11.2. 235

8. Dayan N (Ed.). Skin aging handbook: An integrated approach to biochemistry and product development. William Andrew Inc. 2008. https://doi.org/10.1037/ a0024768 PMid:21787044 PMCid:PMC3202072

9. Bolzán AD. Interstitial telomeric sequences in vertebrate chromosomes: Origin, function, instability and evolution. Mutation research/Reviews in mutation research. Mutat Res Rev Mutat Res 2017;773:51-65. https://doi.org/10.1016/ j.mrrev.2017.04.002 PMid:28927537

10. Hall SS. Merchants of immortality: Chasing the dream of human life extension. $\mathrm{HMH} ; 2003$.

11. Vermaak D, Malik HS. Multiple roles for heterochromatin protein 1 genes in Drosophila. Annu Rev Genet 2009;43:46792. https://doi.org/10.1146/annurev-genet-102108-134802 PMid:19919324

12. Whitman AG, Lambert PJ, Dyson OF, Akula SM. Applications of nanotechnology in the biomedical sciences: small materials, big impacts, and unknown consequences. Emerging Conceptual, Ethical and Policy Issues in Bionanotechnology: Springer; 2008. p. 117-30. https://doi.org/10.1007/978-1-4020-8649-6_8

13. Hartwell LH, Weinert TA. Checkpoints: controls that ensure the order of cell cycle events. Science. 1989:629-34. https://doi.org/10.1126/science.2683079 PMid:2683079

14. Haroon, Ma XM, Li YX, Zhang HX, Liu Q, Su XH, et al. Transcriptomic evidence that insulin signalling pathway regulates the ageing of subterranean termite castes. Scientific Reports 2020;10(1):1-13. https://doi.org/10.1038/ s41598-020-64890-9 PMid:32424344 PMCid:PMC7235038

15. Cinar IO. Bibliometric analysis of breast cancer research in the period 2009-2018. Int J Nurs Pract 2020;26(3):e12845. https://doi.org/10.1111/ijn.12845 PMid:32406145

16. Zhang Y, Quan L, Du L. The 100 top-cited studies in cancer immunotherapy. Artificial Cells Nanomed Biotech 2019;47(1):2282-92. https://doi.org/10.1080/21691401. 2019.1623234 PMid:31169039

17. Karakus M, Ersozlu A, Clark AC. Augmented reality research in education: a bibliometric study. EURASIA J Math Sci Tech Ed 2019;15(10):em1755. https://doi.org/10.29333/ ejmste/103904

18. Merchant Z, Sadaf A, Olesova L, Wu T. A systematic review of research questions in mixed methods studies in instructional design. Pedagog Res 2021;6(4):em0107. https://doi.org/10.29333/pr/11282

19. Ahmad T, Hua L, Khan M, Nabi G, Khan S, Çinar IÖ, et al. Global research trends in pediatric trauma from 1968 to 2021: A bibliometric analysis. Front Pediatr 2021;9:762531. https://doi.org/10.3389/fped.2021.762531

20. Birkle C, Pendlebury DA, Schnell J, Adams J. Web of Science as a data source for research on scientific and scholarly activity. Quant Sci Stud 2020;1(1):363-76. https://doi.org/10.1162/qss_a_00018 
21. McKhann GM, Knopman DS, Chertkow H, Hyman BT, Jack Jr CR, Kawas $\mathrm{CH}$, et al. The diagnosis of dementia due to Alzheimer's disease: recommendations from the National Institute on Aging - Alzheimer's Association workgroups on diagnostic guidelines for Alzheimer's disease. Alzheimers Dement 2011;7(3):263-9. https://doi.org/10. 1016/j.jalz.2011.03.005 PMid:21514250 PMCid:PMC3312024

22. Kawuki J, Musa TH, Papabathini SS, Ghimire U, Obore N, Yu X-J. The 100 top-cited studies on Ebola: A bibliometric analysis. Electron J Gen Med 2020;18(2):em276. https://doi.org/10.29333/ejgm/9694
23. Ahmad T, Khan M, Haroon, Dhama $K$, Jin $H$, Baig $M$. Characteristic features of 100 most influential studies in evidence-based medicine: A worldwide bibliometric analysis. Electron J Gen Med 2021;18(6):em334. https://doi.org/10.29333/ejgm/11321 